\title{
Contributions of Professor Mary Priscilla Dzansi-McPalm to Music Education in Ghana
}

\author{
Samuel Agbenyo \\ Department of Music, University of Mississippi, Oxford, USA
}

*Corresponding Author: Samuel Agbenyo, Department of Music, University of Mississippi, Oxford, USA

\begin{abstract}
Although there are tons of biographical works in research database, there are yet countless, less canonic music scholars whose outstanding input to the advancement of the discourse have not come to the limelight. This historical research therefore, sought to unveil contributions of a pioneering female music educator Professor Mary Priscilla Dzansi-McPalm to the development of music education in Ghana. Using a semi-structured interview, data was collected and analyzed in a researcher interpretive style. Findings revealed Mary from a farming community, born into a musical family, and nurtured both home and abroad to became an astute music education Professor. It was recommended that music instructors determine appropriate modern technological means of unfolding participatory curricular experience in the classroom with sensitivity to the diverse socio-cultural contexts and backgrounds of learners. Emphasis is to be on the teaching and learning process rather than product. Future studies will focus on other less popular music educationists (especially females) in Ghana, West Africa, Africa, and elsewhere whose works, and ideas could help relate the past to the present, and determining the desired future of music education.
\end{abstract}

Keywords: biographical, music, contributions, interpretive, curricular experience, education.

\section{INTRODUCTION}

The importance of biographical works in music education cannot be overemphasized since many music educators often overlook their own contributions to the development of the discourse (Kelly, 1999). Although only two of the thirty-two (6\%) biographical studies in volumes 1-20 of the Journal of Historical Research in Music Education were on women, McCarthy (2012) applauded an increase in the number focused on the lives and contributions of female music educators in volumes 21-30 (p.152). She then recommended further studies on women's contribution and their integration into mainstream music education history, postulating that studies of the careers of individual women music educators will "eventually lead to alternative views of the history of music education" (p.106). Knowing the scarcity of such biographical researches in the Ghanaian context, these extant findings challenged me to attempt investigating the contributions of Professor Mary Priscilla Dzansi-McPalm to Music Education in Ghana.

The paper unfolds with sub-titles including (her) Birth and Early Life, Post-Secondary Musical Education and Training, Research and Publications, Musical Compositions, Main Leadership Roles, Mentors and Mentees, Family Life, Challenges, Post-Retirement Activities and Projections, Summary and Conclusions, followed by References.

\section{Method AND MATERIALS}

Having sought her consent for participation in the study, I scheduled and had an interview with the subject, Professor Dzansi-McPalm on February 18, 2021. I then transcribed the zoom-recorded interview and forwarded the draft transcription to the interviewee for data verification as indicated by Phelps et al (2005, pp. 86-89). There were also few follow-up communications seeking further information from her. After her review and return of the document, I then presented the report using the researcher interpretive approach according to Brain (2002) by constructing meaning from the data. In doing so, I also heeded the caution (Roberts, 2002, p.1) to maintain a balance between facts on the one hand, and my own (researcher) interpretations on the other hand. 


\section{BIRTH AND EARLY LIFE}

Born on May 29, 1956 at Saviefe-Agorkpo, a farming community in the Volta Region of Ghana, West African, Professor Emeritus Mary Priscilla Dzansi-McPalm is the fourth among eight children (three girls and five boys) of Mr. Joseph Dzansi (blessed memory) and Mrs. Clementine Dzansi. Both parents were subsistent farmers who cultivated both cash crops and food crops. She described her father as "chief cocoa ${ }^{1}$ farmer" doubling as a hunter which made him a balanced farmer. Together with her siblings Mary accompanied her parents to the farm. She recalled that it was all joy going to work on the cocoa farm, cassava farm, yam farm, maize and groundnut (peanut) among others because she knew that the farm was the source of livelihood for the family. She unwrapped with a broad smile "I knew that it was the cocoa farm my father used to look after us. ... it was quite interesting, and I had no regret of being born to hard working farmers" (Interview, Thursday February 18, 2021). Both parents were committed Christians in the Roman Catholic St. Joseph church. Her father was a choir leader with vocal virtuosity and melodic charm who taught songs in the church. During each Mass ${ }^{2}$ he selected and intoned songs as well as led the choir or the congregation to sing. Mary begun her musical enculturation by learning several hymns as she observed and listened to her father sing and teach the songs.

At an approximate age of seven, Mary started school straight from class one and continued through middle school form four in her hometown. During that time Kindergarten was not required. Her class one (first grade) teacher was Mr. Gomado of blessed memory. "He was full of life, taught us a lot of childhood songs, danced with us ...he simply behaved like a woman because I know it is women who usually taught class one." According to her narration, Mr. Gamado seldom brought food to class, shared it among the pupils and they all ate together including the teacher. Mary was a very lively girl in the primary school and her parents were really proud of her. Each day, on her return from school her father asked her to tell him all things she learned at school, including singing songs that were sung in school for him-and she did so with great excitement.

Mary's parents did not have formal education. However, they received some level of Adult Education (functional literacy training). So, they could read/write the fundamentals of the native Ewe language. Hence, when her father was preparing to go teach a hymn but was not sure of the lyrical accuracies, he often called Mary, and called out the hymn number, say "Hymn 44", intone it and then ask: "“"Eyaemia?"” (Is that it?) and Mary answered in the affirmative. In rare instances when the answer was "No" he asked Mary to read the lyrics to his hearing in order to enable him ascertain that the right hymn was selected with the corresponding number from the hymnal.

Not only did the then little Mary assist her father with songs but also with letter-writing. The former would often be writing the letter while the latter dictated the contents of several letters which were mailed to relatives and friends both home and abroad. After writing each letter her father would say "“Xlêe mase"" (Read it to my hearing) thus making sure that all corrections were properly done before the document was dispatched. Through that routine, Mary Priscilla Dzansi-McPalm did not only learn several songs in her early childhood days but also developed excellent literacy skills from her father.

In those days, the Atlantic Music Reader was the music curriculum for primary schools in Ghana. Mary could sing all the solfège notations in the book. In the classroom, whenever the teacher asked "who can sing this song in the solfa notation?" the young Mary was the only one who could raise her hand to sing it. The teacher would then ask her to sing, and there she went:

"s. 1: s. f: m: d. d: r: m. $r: t_{1} . s_{1}: s_{1} \ldots$ ". and so forth with very accurate high and low pitches to the admiration of the teacher. Eventually, Mary was assigned the role of intoning songs for group singing both in the classroom and at school gatherings. On entering middle school form one, her role advanced to the selection of songs and intoning same for morning devotion and matching into the classroom each day. She did that for the entire four-year middle school period.

\footnotetext{
${ }^{1}$ Cocoa is Ghana's topmost cash crop with the highest foreign income from the agricultural sector.

${ }^{2}$ Mass, the central act of worship of the Roman Catholic Church, which culminates in celebration of the sacrament of the Eucharist. The term mass is derived from the ecclesiastical Latin formula for the dismissal of the congregation.
} 
The next stage was her five-year secondary education at Our Lady Apostles (OLA) Secondary School, $\mathrm{Ho}^{3}$ where she enrolled in the General Arts program. From forms one through three, all core subjects and all elective subjects were required. These included Mathematics, English Language, Integrated Science (Chemistry, Biology, and Physics), Bible Knowledge (B. K.), Geography, History. Others were Music, shorthand, type writing and Accounting (Business electives). At OLA Secondary School, she met an instructor whom she described as "this wonderful female music teacher" being her role model. Her name was Miss Theresa Fynn. Mary was fascinated to find a lady teacher teaching music at the secondary school level and became highly inspired to become like Miss Fynn. With her already sound musical background, Mary's inclination to music learning became very high. So, at form four when it came to the selection of elective subjects she opted for music-the only student in her batch who elected to do music - all other students in the class abandoned the subject. Although she was the only student left in the music classroom, Miss Fynn was not discouraged from teaching Mary. The female teacher was utterly committed to helping Mary succeed, by offering her meaningful classroom experience as well as engaging her in extra-curricular musical activities. Mary was helping her teacher in teaching hymns to the entire student body including her seniors. She led singing sessions during Masses. Her teacher taught her basic chord progressions on the piano to enable her teach the hymns as well as provide accompaniment during Masses. Sometimes it became necessary for Mary to visit Miss Fynn at home for (piano) lessons. As the student-choir leader, Mary was required to check attendance at rehearsals and list names of absentees for her Boss, Miss Fynn. Occasionally some culprits, especially her seniors took offence on her for allegedly "reporting" them.

In effect, Mary Priscilla Dzansi-McPalm was the sole candidate who wrote the GCE ${ }^{4}$ Ordinary Level final music examination at OLA Secondary School and graduated in 1982. On the day of the final examinations, question papers for all subjects came on time except music. The music paper alone was nowhere to be found among the packs that were brought from the West African Examinations Council (WAEC). The teacher (also a female) who was scheduled to invigilate the music examination waited till she got fed up and started throwing revilement at Mary, being the daring candidate who solely decided to do no other subject among the lot but music. "“Why? Now you see, after waiting for all this while, I have to go home and come back here just because of one-girl-paper!"' Prof recalled the teacher's words, still smiling. Eventually however, the music paper finally arrived. She wrote it, and passed with excellence.

\section{Post-Secondary Musical Education ANd Training}

After the music program at OLA Secondary School Mary won a scholarship in 1982 from the Catholic Diocese to pursue a Bachelor of Arts Music program, in Ursuline College, Cleveland, Ohio Cum Laude and graduated as a certified music educator in 1986. Her undergraduate class roll was six students. Two female music professors in Ohio who were Mary's role models were Rosemary Hozdic her Harmony instructor, and Janet Moore, her vocal instructor. Although she was a voice major, she learned to play several other required instruments such as violin, clarinet, and trombone. As part of her teacher training, she was sent to Villa Angela Senior High School on teaching practice where she resided and taught music for six months under the supervision of her co-operative teacher. Aside learning instructional skills Mary learned to arrange songs in three parts, taught the songs and conducted during Christmas and other concerts, attracting complements from her co-operative teacher Mary Jones, the school community and the parents. Consistently, she spent time learning to conduct in front of dressing mirror in her apartment as well as in the mirror room at school, leading to her impressive renditions during concerts. Not only did she conduct but also participated in the school orchestra. Mary played trombone, clarinet and violin in various performances. Some of her favorite pieces were "Memories", "Bells Bells" very contrapuntal arrangement for Christmas and other school concerts.

While at Villa Angela Senior High School, Mary assisted in piano lessons in a nearby piano laboratory for children thus using the opportunity to improve her own piano skills with the help of a private instructor. Sometimes, the "instructor and I would play the primo and the secundo respectively

\footnotetext{
${ }^{3}$ The capital city of the Volta Region, Ghana

${ }^{4}$ General Certificate of Education
} 
of some selected pieces" Mary recalled. After graduating from the teacher training program in Cleveland, Ohio, she returned to Ghana in 1986 and was posted by the Ghana Education Service (G.E.S.) to St.Theresa's Teacher Training College (now St. Theresa's College of Education), a female teacher training institution at Hohoe in the Volta Region of Ghana. The college is popularly called "Theresco". She taught music at Theresco for six to seven years (1986-1992) where she handled both the college choir and other choirs in the town. She had several recordings of the college choir by the Ghana Broadcasting Corporation (GBC) which were played nationwide. The national radio program was dubbed "Campus Melodies" aired every Monday from 3:00pm to 3:30pm.

Every Monday, even when I was driving and it was three ' $\mathrm{O}$ ' clock I would pack my car and listen to my choir to know how we were sounding on air, and drive on after the session. Theresco choir, led by Mary Priscilla Dzansi was the leading name on campus melodies and my choir was frequently invited to sing at so many functions (Interview: February 18, 2021).

In 1991 Mary enrolled for her M. A. Musicology degree at University of Ghana, Legon where she was one of the seven-member female choir (they were only seven females in the music department) and graduated in 1993. She then applied for a lectureship position at the then University College of Education, Winneba (UCEW) now University of Education, Winneba (UEW) where she taught music till date. In 1999, Mary proceeded on a Fulbright Scholarship at the University of Illinois, UrbanaChampaign where she was awarded a Ph.D. (Music Education) in 2003 and returned to teach in UEW till her retirement in 2016. She was the proud recipient of the prestigious Marilyn Zimmerman award in U of I, department of Music.

\section{ReSEarch AND Publications}

Mary had a multicultural-interdisciplinary research interest as reverberated in her works, encompassing topical areas such as African Arts as Cultural Expressions in Ghanaian Schools, Popular Music in Music Education, and Gender Studies in Creative Arts. However, her primary focus was on what she framed in her curriculum vitae as "Children's Singing Games: Foundation and Approach to Music Teaching and Learning" Professor Mary Priscilla Dzansi-McPalm, primarily with a blended Orff-Schulwerk -Zoltan Kodály (Choksy, 1974, p. 9)) philosophical inclination, premised in the Ghanaian-multicultural context believed in building sound foundation in children as the surest means of promoting successful life-long music education. Therefore, most of her publications focused on children's music-Singing Games. Her writings were mainly aligned with the Ghanaian background of children's game songs. Some of her published works include: What's in a singing game? (2013), Their World of Play: Our World of Education (2011), Aestheticismin African Musical Arts: Philosophical Underpinnings (2011), Our women drummers: Cultural influences on female participation in instrumental music (2010), Come let us play: Musical games from Ghana (2010), Music Cognition, reflections on Fiske: Implications for instruction (2009). Playground music pedagogy of Ghanaian children (2004), from bells to talking drums (2004). Some manifestations of Ghanaian indigenous culture in children's singing games (2002). Critical issues in arts education: Reflection on Eisner and music educators. Play in musical arts pedagogy (2003), Music and Dance for junior secondary schools: A handbook for teachers, volumes 1-3 (2004) to mention but a few. He musical compositions included but not limited to Shine on me, a three-part choral (for female voice) Recorded at GBC for Campus Melodies, Deviwo nye yayra (Children bring blessing) a three-part choral for elementary choral competition performed by the Volta Region Elementary schools, $O$ little flower (St. Teresa), a three-part choral composition for St. Teresa Female Teacher Training College performed as a school anthem, and recorded at GBC for Campus Melodies, Mizכ yi ng kple Kristo (Move forward in Christ), an SATB composed for the centenary celebrations of the Catholic Diocese of Keta-Ho in the Volta Region of Ghana in her capacity as the Regional Director of Catholic church choirs.

Asked what was her motivation for compositions and publications, Professor Dzansi-McPalm expressed her dream as a music educator to leave a legacy for posterity. Having read and performed works of many music educators, she nurtured an avidity to contribute to extant repertoire and literature in the discipline. While learning from other people's works, she saw the reciprocal need for others to learn from her works too. "It is motivating for people to cite me in their publications just as I 
have also cited others in my works" she revealed. She recalled that while engaged in voracious reading of several works at the University of Illinois, Urbana-Champaign, she realized gaps in some of the older publications that could be filled from the Ghanaian perspective, and decided to write in order to fill in some of the gaps. She noted that such gaps had to do with laying the foundation for children's music education using scaffolding strategies. That was to indicate how imperatively we must start music education from the grass root based on the Ghanaian background of the learner; instead of tardily starting music the child's music lessons higher grades of schooling.

In another dimension, she partly credited her publication motivation to the fact that researching and publishing constitutes an essential part of her work as a university faculty member. This was not just for promotions but first and foremost as demonstration of scholarship, geared towards helping solve music education problems while adding to knowledge in the discourse.

\section{Musical COMpositions}

Her compositional inspiration was traced to her participation in music festivals in Ghana as an adjudicator. As people's compositions were found useful for school competitions, she realized a possibility to contribute to repertoire for that purpose, still directing attention to children. She had an urge to join Ghanaian composers who were projecting the Ghanaian culture through school children by means of musical compositions. Her first composition Đeviwo nye yayra (Children bring blessing) drew its title from the words of her father (back in her childhood days). Her father often described children as blessings to their parents. The same year, 1988 that she composed this song, it was selected for competition at elementary school level in the Volta Region of Ghana.

Besides, her October 1990 SATB Mi zכyi `g kple Kristo (Move forward in Christ) was the selected anthem which was performed during the centenary celebration of the Catholic Diocese of Keta-Ho in the Volta Region. Aside that church choirs in the Ho District sang a lot of her songs not to mention her own hometown (Saviefe-Agorkpo) St. Joseph Catholic church choir which sang her songs proudly and habitually. They do same till date. Prof. Dzansi-McPalm excitedly disclosed that even the old folks in the choir including her mother (with a beautiful alto) still sing impressively despite their advanced ages. "Whenever I attend a mass in my hometown, they make sure to sing some of my songs" she added. She acknowledged Dr. George Worlasi Kwesi Dor, currently a Professor of Ethnomusicology at the University of Mississippi, U. S. A. as one of the renowned Ghanaian composers who discovered her compositional potential and encouraged her to do so as part of her contributions and legacies for posterity. "And don't forget my own husband, Mr. Korkuvi McPalm. $\mathrm{He}$ is a great composer who really inspired me, and I took some cues from him" she credited.

\section{MAIN LEADERSHIP ROLES}

Apart from the roles played as a student-music teacher (from the primary school through the university), Mary served in many capacities both in the community and in the university. For forty years she had been the Volta Regional Diocesan choir director of the Catholic Church of which she has been a devoted member. The Volta Regional Diocese of the Catholic church in Ghana runs from Keta (in the south) to Kete Krachi (in the north). With her team of trainers, she organized annual clinics for the choirmasters. At the University of Education, Winneba as soon as she was recruited, she was assigned the Head of the Voice unit in the music department. Subsequently, she became head the Western Music unit as well as the mixed chorus leader. She took the departmental choir to perform on several occasions at the studios of the Ghana Broadcasting Corporation (GBC), patronized nationwide, of course including the university community. From unit headship, she was elevated to the Head of Department (Chair) position in 2005. Unusual among her leadership roles was the appointment as the head of Arts Education Department. Her attempt to resist that appointment on grounds of being a music educator not "art" educator was unsuccessful. So, she took up that challenge from 2006 to 2008 .

In addition to the Arts Department, she had a pioneering oversight responsibility for the newly created Theatre Arts Department, all within the then Division of Cultureand Social Sciences. She was later appointed the Dean of the School of Creative Arts (SCA) during which tenure she introduced the $\mathrm{Ph} . \mathrm{D}$ (Arts and Culture) program, the Bachelor of Music Program (for non-music teachers) the Vacation Music Camp (Summer equivalent) program and the Vacation Theatre Art Camp. The vacation programs, apart from serving as a refresher opportunity for interested musicians also became 
an effective avenue enrolment drive. In 2009 she led the creation of the Graphic Design Department bringing the number of departments to four in the SCA. Furthermore, it was during her 9-year tenure as the Dean that the music education department procured a large quantity of orchestral instruments and equipment and started the orchestral unit. As a Head of Departments and Dean, Prof. DzansiMcPalm served on several Boards and Committees of the university. These included Academic Panning, Academic Board, Appointments and Promotions Board, The Library Board, Executive Committee, ICT for Development (ICT for D) Committee on which she toured several African and European countries to understudy their use of ICT in higher education. Others included the Board of University Endowment Fund, the Faculty Board, and many Departmental Committees. She also served as the Vice-Chair for the Local Organizing Committee (LOC) for the hosting of the Ghana Universities Association (GUSA) Games at the University of Education, Winneba. During the $25^{\text {th }}$ anniversary celebration (Silva Jubilee) of UEW Professor Mary Priscilla Dzansi-McPalm was the Chair of the planning committee.

\section{Mentors And Mentees}

Besides the musical influence of her parents, teachers, and spouse on her development, Mary acknowledged Professor Emeritus James Emmanuel Flolu as a mentor during her formative working years in the University of Education,Winneba. The latter who happened to be the predecessor of the former as Dean of the School of Creative Arts pulled her along by assigning various roles, and coaching her until he (the mentor) was transferred to the erstwhile Kumasi campus ${ }^{5}$ of the university, at which time Mary was appointed to take over as the Dean of the school.

She also expressed a great extolment to Prof. Emeritus Jophus Anamuah-Mensah ${ }^{6}$ who identified the potentiality and tasked her with various challenging roles, all of which culminated into her current status. Mary did not forget to mention her role models at the University Illinois where she pursued her Ph.D (Music Education). They were Professor Emeritus Eve Harwood and Professor Liora Bresla who taught her as well as gave her the opportunity to teach other (international) students. She in turn has mentored and groomed countless number of her students into academia and the music industry. Some of her mentees include Prof. (Rtd) Eva Akosua Ebeli, Prof. Emmanuel Obed Acquah (current Director of Quality Assurance), Dr. Augusta Arko-Mensah (Senior Lecturer), Dr. George Asabre Maclean (Lecturer), Dr. Hans Kweku Anderson, Mr. John Francis Annan (current Head of Department), Mr. Michael Anthony Kwesi Adomina (Lecturer) all in the Department of Music Education, UEW. Others are Dr. Kofi J. S. Gbolonyo (Adjunct Professor of Ethnomusicology and African studies at the University of British Columbia, Vancouver, Canada/Founder and Director of Ghana's Nunya ${ }^{7}$ Academy), and Samuel Agbenyo (author, and Ph.D. Music Education student/Graduate Teaching Fellow at The University of Mississippi, USA), among others.

\section{FAMILY LIFE}

Mary is married to Mr. Edward Korkuvi MacPalm, also a renowned Ghanaian composer. They have several indistinguishable biological and adopted children at various levels of diverse accomplishments. Most of these people are children of family members who she (together with her husband) has taken care of especially from their (the children's) secondary schools through the tertiary levels.

\section{Challenges}

The first challenge that run through her music career was coming from a Western music background as a teacher to adopt and adapt to her own culture in music teaching and learning. Prof must then look for local repertoire and the apprenticeship method that she advocated for in her PhD Dissertation to suit the music reforms in Ghana.

\footnotetext{
${ }^{5}$ The Kumasi campus is now an autonomous university with the name Akenten Appiah-Menka University of Skills Training and Entrepreneurial Development. (AAMUSTED)

${ }^{6}$ The first Vice Chancellor of the University of Education, Winneba

${ }^{7}$ Wisdom
} 
She recounted that on her arrival at St. Theresa's Training College as a relatively young female music instructor, she had come fully enthusiastic with so much instructional materials from her first degree from Cleveland Ohio (USA). "Because I had enjoyed the listening and other western music lessons in the United States, I was poised to do the same in Ghana." But she had to contend with the fact that musical abilities of the generalist teacher trainees were far below the level of material she had imported to teach them because they did not have as sound music literacy foundation as compared their peers in the Western culture. Regardless, Mary persevered with her students, having a sense of optimism to see results progressively. Unfortunately, her co-music teacher insisted that she must stop using her materials entirely and resort to the use of the existing 'comfort zone' curriculum.

\begin{abstract}
So, I had to adjust and adapt by coming down to what they were doing prior to my arrival but fought through by doing my best to go beyond what I came to meet. That was how come I managed to get the campus melody running all the time. I was determined to get my music students recognized nationwide. Hence, I even organized the ABRSM tuition for them, and some of them had some good grades in the tests eventually (Interview: February 18, 2021).
\end{abstract}

On assumption of duty as the first female dean of the School of Creative Arts at the University of Education, Winneba a strong challenge was her realization of some sort of division among the maledominant faculty. It took her an appreciable effort to get the antagonizing offshoots re-united and motivated to excel toward their current individual and collective levels for which the entire faculty had become grateful. Also, the interviewee recalled inadequate supply of music instructional materials at the university as one of the remarkable bottlenecks during the initial years. It was difficult to have two or more instructors teaching simultaneously because instruments - pianos, winds, strings, drums, gyile (zylophones), et cetera - were in woefully short supply. It took a great deal of tact to get lessons taught and a resilient approach to procure instruments and equipment for the music department. Currently the department is impressively resourced with all manner of instruments and other facilities necessary for effective music teaching and learning.

\title{
11. Post-Retirement Activities And Projections
}

While still teaching some graduate music education courses, supervising theses/dissertations, and serving on some university boards/committees on post-retirement contract, Professor Mary Priscilla Dzansi-McPalm has tons of materials that she is relentlessly planning to publish into books and journal articles for the benefit of the music education fraternity. "Retired does not mean that your scholarship has ended. I need to publish more books on music in early childhood as well as community music, to make sure that I have adequate texts for the schools and my department..." She also planned to continue supervising theses and dissertations both within and without UEW in addition to visiting the church and community choirs so as to lend them needed supports. Not only that but also, she hoped to compile community songs (old songs/folk songs) "that are gradually phasing out." She intends to arrange them with their synopses for use at various grades of posterity.

\section{SUMMARY AND CONCLUSIONS}

Professor Mary Priscilla Dzansi-McPalm had a head start in music learning with the help of her father. She utilized opportunities as a song leader and student-teacher to nurture her musical talent at various stages of education both in Ghana and in the United States of America. As a faculty member, she served as unit head, departmental head, and dean, not without hurdles. She was also present on several boards and committees. Her leadership resulted in advancements in programs as well ashuman and material resources of the music department in UEW. Apart from her musical contributions to educational institutions and the church, she had many scholarly publications to her credit while determined to do more for the current generation and offer a legacy for posterity. Professor Mary Priscilla Dzansi-McPalm's diverse contributions have helped to promote music education in Ghana, and she remains a reference point as well as a source of inspiration for the music education fraternity.

In view of the seemingly kaleidoscopic nature of the Ghanaian music education system since the country's colonial era, Professor Mary Priscilla Dzansi-McPalm concluded by urging music educators to be abreast with current trends and problems in music instruction within the schools and determine appropriate modern technological means of unfolding participatory music teaching and learning in the 
classroom with sensitivity to the diverse socio-cultural contexts and backgrounds of their learners. That way we can ensure robust multicultural music education programs with more emphasis on the teaching and learning process than product (examinations) thereby making music appealing to students in the $21^{\text {st }}$ century Ghana. In a further research, students of Professor Dzansi-McPalm will be interviewed in addition to reviewing historical records in the music department of UEW for a more saturated data. Also, there is need to conduct similar studies on other less popular music education legends (especially females) in Ghana, West Africa, Africa, and elsewhere whose works, and ideas could contribute towards relating the past to the present, and determining the desired future of music education.

\section{REFERENCES}

[1] Choksy, Lois. The Kodály method: Comprehensive music education from infant to adult. Englewood Cliffs, NJ: Prentice-Hall, 1974.

[2] Dzansi-McPalm, Mary Priscilla “Curriculum Vitae” Unpublished document.

[3] Dzansi-McPalm, Mary Priscilla. Interview with Samuel Agbenyo. 60 Minutes. Zoom, February 18, 2021.

[4] Dzansi, Mary. "Playground music pedagogy of Ghanaian children." Research Studies in Music Education 22, no. 1 (2004): 83-92.

[5] Dzansi-McPalm, Mary Priscilla. Children's playground music as cultural expressions in Ghanaian schools. University of Illinois at Urbana-Champaign, 2004.

[6] Kelchtermans, Geert. "Narrative-Biographical Research on Teachers' Professional Development: Exemplifying a Methodological Research Procedure." (1999).

[7] Kelly, Steven N. "John Barnes Chance and his contributions to music education." Journal of Historical Research in Music Education 21, no. 1 (1999): 21-40.

[8] McCarthy, Marie. "Developments and Trends in Historical Research as Reflected in the Journal of Historical Research in Music Education, Volumes 21-30 (1999-2009)." Journal of Historical Research in Music Education 33, no. 2 (2012): 152-171.

[9] Phelps, Roger P., Ronald H. Sadoff, Lawrence Ferrara, and Edward C. Warburton. A guide to research in music education. Scarecrow Press, 2005.

[10] Roberts, Brian. Biographical research. Buckingham: Open university press, 2002.

\section{AUTHOR's BIOGRAPHY}

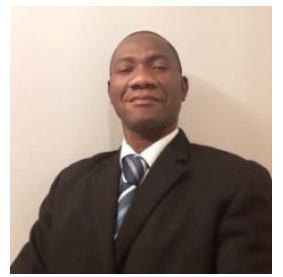

Samuel Agbenyo, (PhD, Arts and Culture) is a faculty member in the Department of Music Education, University of Education, Winneba. He is currently pursuing another doctoral degree in Music Education in The University of Mississippi, Oxford, U.S.A. He is passionate about Inclusive Music Teaching and Learning.

Citation: Samuel Agbenyo. " Contributions of Professor Mary Priscilla Dzansi-McPalm to Music Education in Ghana” International Journal of Humanities Social Sciences and Education (IJHSSE), vol 8, no. 10, 2021, pp. 21-28. doi: https://doi.org/10.20431/2349-0381.0810004.

Copyright: (C) 2021 Authors. This is an open-access article distributed under the terms of the Creative Commons Attribution License, which permits unrestricted use, distribution, and reproduction in any medium, provided the original author and source are credited. 